
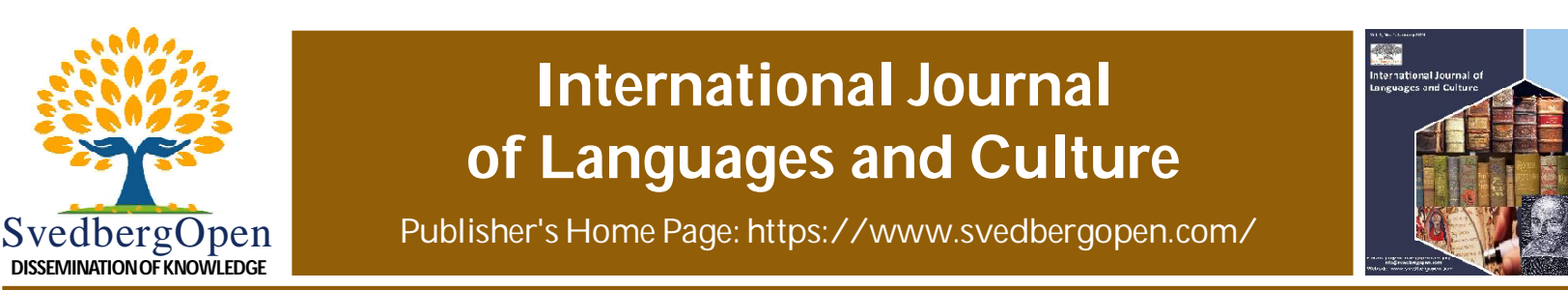

Research Paper

Open A ccess

\title{
Between the praise and defense of nature: An eco-critical discourse of Niyi Osundare and Tanure Ojaide's eco-poetry
}

\author{
Oluwafemi Sunday Alabi ${ }^{*}$ \\ 'Department of English, Obafemi, Awolowo University, Ile-Ife, Nigeria. E-mail: oluwafeminitemi@gmail.com
}

\section{Article Info}

Volume 1, Issue 2, June 2021

Received : 14 January 2021

Accepted : 17 May 2021

Published : 05 June 2021

doi: $10.51483 /$ IJLC.1.2.2021.1-7

\begin{abstract}
One critical area that the poetry of Niyi Osundare and Tanure Ojaide addresses is naturethe physical environment. Hence, their poetry is classified as eco-poetry. Although studies on the poetry of Niyi Osundare and Tanure Ojaide have focused on traditional aesthetics, political power, exile and African experience (Ojaruega, 2015; Tsaaior, 2011; Nwagbara 2008, 2010; Okunoye, 2011) sufficient studies have not been done on their defense of natural environment. This study examines how their poetry celebrates nature and how they are used to caution the imminent danger of mismanagement of the physical environment. Thus, Niyi Osundare's The Eyes of the Earth and Tanure Ojaide's Delta Blues \& Home Songs are studied to provide insights into the forms, patterns and concerns of their ecopoetry. The study leverages eco-criticism - the study of the relationship between literature and the natural environment-as its theoretical insight. The paper contends that though these poets celebrate nature's beauty and potentials, their poems chastise exploitative activities of man and urge moral and social change in favor of the natural environment. It equally argues that the poets' particular environments influence the form and style of their poetry, maintaining that there are more environmental challenges in the contemporary world of Tanure Ojaide which his poetry reflects in contrast to Niyi Osundare's.
\end{abstract}

Keywords: Environment, Nature, Eco-criticism, Nature-poetry/Eco-poetry

(c) 2021 Oluwafemi Sunday Alabi. This is an open access article under the CC BY license (https://creativecommons.org/licenses/by/4.0/), which permits unrestricted use, distribution, and reproduction in any medium, provided you give appropriate credit to the original author(s) and the source, provide a link to the Creative Commons license, and indicate if changes were made.

\section{Introduction}

Poetry is

what the soft wind

musics to the dancing leaf

what the sole tells the dusty path

what the bee hums to the alluring nectar

what rainfall croons to the lowering eaves.

(Niyi Osundare's Songs of the Marketplplace $(1983,3)$

The above stanza in Niyi Osundare's Songs of the Marketplace ("Poetry Is") best describes what poetry, nay poetry of nature is - celebrating and defending the nature. Jeff (2009), tracing the treatment of nature in poetry from the classical

\footnotetext{
* Corresponding author: Oluwafemi Sunday Department of English, Obafemi, Awolowo University, Ile-Ife, Nigeria.

E-mail: oluwafeminitemi@gmail.com
} 
period, medieval, neo-classical, to romantic period, submits that the treatment of nature in literature "comes from the apprehension of the created world as evidence for the existence of God and His benevolence" (68). He opines that from classical to romantic period, poets have been concerned with the various aspects of physical nature like the Earth, the rocks, trees, night and stars.

Ojaide (1995), in his Poetic Imagination in Black Africa, notes that what informed eco-poetry in Africa and in particular Nigeria is "senseless destruction of our original neighbors, the trees and animals" (16), which he contends powerfully against. Again, Nwagbara (2013) argues that the 'commodification' of the natural world through the practice of global capitalism has necessitated eco-poetry. He argues further that the much talked about environmentalism, ecopoetry and ecocriticism stem from an ideological provenance to resist the dogma of commoditization of relations mediated through globalization or capitalism (200). Thus, Nigerian writers have risen to the occasion - by using literary art to address as well as to bring to the knowledge of humanity this form of environmental devastation and inhumanity of man to nature.

Anyokwu (2015) claims that "the environmentally-conscious poet uses nature-flora and fauna-to establish a sense of local habitation to the so-called 'airy nothings' that constitute part of the flesh-and-blood of his poetry" (8). Thus, the nature or natural environment has become recurrent images and themes in the poems of certain African poets particularly Nigerian poets, the likes of Niyi Osundare, Tanure Ojaide, Christopher Okigbo, Ken Saro-Wiwa, Odia Ofeimun, and Nnimmo Bassey among others.

Aspects of nature like the landscape, seascape and heavenly bodies-like sun, moon, and star are frequent images in their poems. There is also what Fortress Ayinuola (2013) calls "Lifescape", which according to him "[L]ifescape features are represented in degrees of consciousness in a living essence like man, flora or fauna" (11). There are also recurrent images of seasons and beauty of specific sceneries in their poems. These are largely found in the pattern of words used or in repeated phrases in most of their poems.

In all encompassing words, natural environment refers to the physical set-up which encompasses earth, air, water, land, trees, fauna, flora, rivers, lakes, mountains, hill, valley, the seasons and all original inhabitants of a given geographical location which can be harmed by man's activities. And in the words of Ojaide, it is "our original neighbors, the trees and animals" (16). Ayinuola attempts grouping these into three domains of nature, ranging from nature dominated environments to human culture dominated environments which are: (a) the wildernesses, e.g., deserts, oceans, inhabited continents, forests, mountains, cliffs, waterfalls and lakes; (b) the countryside e.g. hills, fields and woods; and (c) the domestic picturesque - man made natural environment, e.g., parks, gardens and lanes. According to him, these area groupings overlap and move gradually from nature to culture (11).

\section{The eco-poetry of Eulogy and optimism in Niyi Osundare's The Eye of the Earth}

Niyi Osundare is no doubt a prolific writer from the southwest of Nigeria who has published a number of poetry collections, drama and books on literary criticism. His poetry collections include The Songs of the Marketplace (1983), Village Voices (1984), The Eye of the Earth (1986), Moonsongs (1984), Waiting Laughers (1990), Midlife (1993), Songs of the Season (1999), Horses of Memory (1999) and The Word is an Egg (2000).

Osundare is a poet of nature and he is noted for the survival of the earth as well as the attendant environmental issues (Ohaeto, 2003). Osundare, in an interview with Stephen Arnold, captures his sense of eco-poetry thus:

I grew up seeing people singing and dancing in praise of Osun. But it's not just a river. It is also water...if we talk of the water and the river we also talk about the rain. The rain is also an icon I use frequently. Because for me the moon unites the earth and the sky — in a way, when the rain is falling it is as if the sky was making love to the earth (Arnold, 2001).

This apparently shows that Osundare's rustic background informs his environmentalist or 'Nature' thinking impulse and writings. In Osundare's poetry, nature is deployed as a 'leitmotif or an organising principle' and he as well illustrates both the possibilities and practice of using natural phenomena in fashioning poetry relevant to the concerns of the society and generation (Anyokwu 2015; Ohaeto, 2003).

Hence, Osundare's eco-critical concern for the environment in The Eye of the Earth is captured in the preface of the collection thus:

Waters are dying, forests are falling. A desert epidemic stalks a world where the rich and ruthless squander earth's wealth on the invention of increasingly accomplished weapons of death, while millions of people perish daily from avoidable hunger. Tomorrow bids us tread softly, wisely, justly, lest we trample the eye of the EARTH

(The Eye of the Earth xiii). 
In The Eye of the Earth, the elements of nature - the forest, rocks and rain are employed as metaphors for the exploration of life and the activities associated with farming (Ohaeto, 2003). Thus, Osundare's preoccupation in the collection include emphasis on human responsibilities and actions to save Nature, aesthetics of reconciling humanity with Nature, a critique of capitalists' commodification of Nature and the environment, the dynamics of eco-poetry or ecocriticism in reclaiming Nature, and the impacts of global capitalism (Nwagbara, 2013).

In the "Earth" which is of course the first poem in the collection, Osundare uses the metaphor of the earth as the ephemeral house of man "Temporary basement" and also his "lasting roof", perhaps after the death of man. He further celebrates the earth as the source of food: "breadbasket /and compost bed" and also reveals its relationship with other nature embodiments such as "rocks", "rivers", "muds", "mountains", "sea", "moon", and 'roving sky" (The Eyes of the Earth 1).

In the first movement, the opening poem, 'Forest Echoes', introduces us to the poet's "wandering feet" which is lured into the forest which the poet speaker calls Oke Ubo Abusoro from where he allows his "perfumed memories" (3) to flow unhindered. In this poem, "Osundare depicts man, the land, animals, plants (in fact all of nature) interacting and celebrating in one festive mood at this time of universal productivity" (Jeff, 2009). This is best captured in stanza six of the poem:

This is Oke Ubo Abusoro,

the distant forest which shames the lazy leg

where the oro tree hawks lofty fruit

for the blue children of a hungry sky

where pampered yams break heaps' bounds

and the plantain leans earthwards

with the joy of heavy harvest.

This is Ubo Abusoro

where my first faltering steps

broke the earthworm on the path of dawn (4).

In 'The Rocks Rose to Meet Me', the poet persona recounts his encounter with the rocks which is another feature of natural environment, using the metaphor of "passionate lovers on a long-awaited tryst" (12). Here, we see the poet speaker standing and waiting before the rock of Olosunta, which begins to address him thus:

"You have been long, very long, and far",

said he, his tongue one flaming flash

of unburnable gnomes

"Unwearying wayfarer,

your feet wear the mud of distant waters

your hems gather the bur

of farthest forests:

I can see the westmost sun

in the mirror of your wandering eyes." (13).

The poet-speaker identifies the rocks as possessing certain valuables; the speaker sees the rocks as the "house of ivory", "god and gold" (12). The persona goes ahead to describes different varieties of rocks: "The rocks rose to meet me / Tall rocks, short rocks, / sharp rocks, round rocks: / some with the staid steps / of war-wise warriors / others with the gaysome gaits / of pandering pilgrims. (14)

Also, in the "Harvestcall" the earth is celebrated as the source of increase and production. The earth is seen as fertile and generous, "capable of producing abundant food and wealth for the benefit of man" (Jeff, 2009). Particularly a product of the earth which is yam is celebrated as the king of crops: “...yams, ripe and randy, / waged a noisy war against the knife. // ...yam wore the crown / in the reign of swollen roots / amid retinue of vines and royal leaves" (17).

The second movement, 'rainsongs' projects the essentiality and inevitability of 'rain' to humanity. Starting with 'Let Earth's Pain Be Soothed', the poet-speaker conveys the anguish that betides humanity when it refuses to rain. Thus: "The sky carries a boil of anguish" and refuses to "burst" making the earth "painful' and unbearable to dwell (27). This is what Jeff sees as the Nature being "angry with man" as a result of the "despoliation of the earth, its resources, and its ecological balance" (Jeff, 2009). Thus, Osundare's tone in the poem is basically that of invocation - pleading with the rain to fall with the employment of repetition of the phrase: "Let it rain today" or "Let it rain" (27). 
In the subsequent poem, 'First Rain', the persona is of the assurance that "when the first rain has just clipped.../ our earth breathes again" (28). This reveals the significant of nature to man - the import of which is made manifest in, "Raincoming": "the rain unties the farmer's tongue, / bursting famine yawns" (29). And in the 'Raindrum', the rain makes "...the throbbing earth renewed" (31). And as metaphorically adumbrated in "Who Says that Drought Was Here", the rain is also the rejuvenator of the earth's 'dwellers' - 'plants', 'herbs', 'leaves', 'twigs', 'wing termites', 'butterflies' fledgling flowers', 'mushrooms', and the host of them: "these guests around" (33). However, in 'But Sometimes When it Rains', Osundare gives us the other side of the rain whose "angry thunder raps earth's ears / with its hand of fire". And also, "sometimes when it rains", "a heartless storm beheads / the poor man's house" (35).

Worthy of examination is the poem "They Too are the Earth" in third movement of The Eye of the Earth, entitled 'homecall'. The poem articulates the suffering of humanity, especially the poor who also belong to the earth and suffer on its surface: "the swansongs of beggars [who] sprawled out in brimming gutters". The poet-speaker uses the metaphor of the "snakeskin shoes and Mercedes tyres" to depict the wears of the poor (43). These are the hordes of beggars on the streets, the hewers and carriers of wood, the suffering women who die unknown in the villages; they are all children of the earth.

Also, in "What The Earth Said", Osundare celebrates the earth, personifying it as capable of exposing the evil that men do - the crimes committed by the people at the helms of affair: "native executhieves", "factorylords" (44). Moreover, it reveals the kind of life live by the poor - they: "toilwards in the dreary dawns", "labouring mouths famished" (44). Thus, the earth as the receiver of all these people at their death has been able to 'hear', 'see', 'shake hands with', 'touch' these categories of people. More particularly the earth "I have seen / lives snuffed out like candles in the storm" (44), and it is now saying:

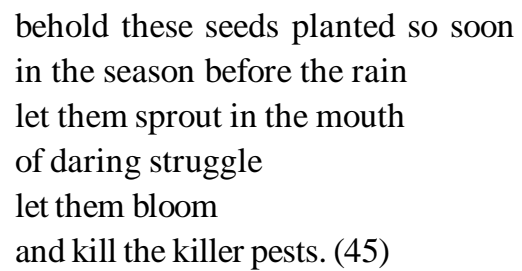

In "Ours to Plough, Not to Plunder", the poet-speaker invites us to conserve our environment; thus: "The earth is ours to plough and plant / the hoe is her barber / the dibble her dimple" (46). The poet's tone here is that of invitation to be eco-friendly, nature-amiable and environmental-caretaker - emphasizing in the last stanza that:

This earth is

ours to work not to waste

ours to man not to maim

This earth is ours to plough, not to plunder. (47)

The last poem in The Eye of the Earth, "Our Earth Will Not Die", is elegiac in mood and tone. Osundare speaks against the senseless subversion - 'lynching', 'slaughtering', and 'mauling' - of our natural neighbours - "the lake", "the seas", 'the mountains'; in all the flora, fauna, and rivers, for capitalistic purpose. However, Osundare is optimistic that: Our earth will see again / eyes washed by a new rain / the westering sun will rise again / resplendent like a new coin.... / Our earth will see again / this earth, OUR EARTH(49).

\section{Tanure Ojaide's polemical style and pattern in Delta Blues and Home Songs}

Tanure Ojaide is an eco-poet whose poetry has challenged environmental injustice, and whose poetic artistry has been used to 'polemicise' capitalistic practice of the imperialists whose activities have led to the destruction of the nature. As submitted by Uzoechi Nwagbara "The hallmark of Ojaide's art is to use literature to engage the realities in his milieu" (Nwagbara, 2010). Thus, Ojaide uses literature for environmentalist purposes. Ojaide's poetry works include: Labyrinths of the Delta (1986), The Blood of Peace and Other Poems (1991), Delta Blues \& Home Songs (1998) and Daydream of Ants and Other Poems (1997), When It No Longer Matters Where You Live (1998), The Tale of the Harmattan (2007) and Waiting for the Hatching of the Cockerel (2008), among others.

Most of Ojaide's poems highlight and deal with the system of exploitative environmental policies that place the multinational corporations, which are represented by Shell, AGIP, Texaco, Chevron, and Mobil as well as the political elite above the people (the subaltern), thereby destroying the Nigerian environment (Nwagbara, 2010). The overview of Tanure Ojaide's Delta Blues and Home Songs (Delta Blues in subsequent references) is subtly captured in the collection's blurb: 
Delta Blues and Home Songs is a poetic diatribe against the environmental degradation of the Niger Delta and the unjust system which makes the people to be chief mourners and paupers in the midst of their oil wealth. (Delta Blues and Home Songs, blurb)

Delta Blues, among some other things, launches attack - like most of Ojaide's poetry — on the degradation of the environment, particularly of the Niger Delta. Ojaide descries homespun and international domination - capitalist imperialism. The collection consists of two parts: first, 'Delta Blues', and second, 'Home Songs'. The first part contains twenty-eight poems, while the second part contains 23 poems.

The first poem in the collection that gives serious attention to the onslaught on the bioregion of the Niger Delta by the capitalist imperialists and its aftermath is "When green was the lingua franca". The persona recounts his "childhood" days how nature was in its right order, "teeming with life" (Delta Blues 12). Here, Ojaide identifies various embodiments of natural environment to include: "water sparkled", "glamorous fish", "earthworm", "snails and koto", "Urhurhu grapes", "owe apple", "cherries and breadfruit", "the cotton tree", in short the flora and fauna. Everything was in order until the coming of the capitalist imperialists who "broke the bond", thus:

Then Shell broke the bond

with quakes and a hell

of flares. Stoking a hearth

under God's very behind!

Explosions of Shell to under

mine grease-black gold

drove the seasons mental

and to walk on their heads.

$\cdots$

I see victims of arson

wherever my restless soles

take me to bear witness

...

(Delta Blues 13)

"Season" also laments the damage that oil does to the Niger Delta environment which "infects with stink" (15). Also the poems like "Wails", "Immortal grief", and "Delta blues" lament the subjugation of nature. For instance, in "Delta Blues", the poetic persona recounts how his birthplace, "share of paradise" experiences "an immeasurable wound" from "Barrels of alchemical" (Delta Blues and Home Songs 21). The persona laments thus:

This share of paradise, the delta of my birth,

reels from an immeasurable wound.

Barrels of alchemical draughts flow

from this hurt to the unquestioning world

that lights up its life in a blind trust....

$\cdots$

My nativity gives immortal pain

masked in barrels of oil -

I stew in the womb of fortune.

....(21)

In essence, the poet-speaker laments how oil companies and national exploiters have without impunity wrecked damage to his native land. Obviously, the poet makes it clear that there had been a sustainable peace in the land prior the discovery of oil in the region. The invention has actually led to the destabilization of peace, prosperity and health of the region. Thus, Ojaide's eco-poetic sensibility is represented in bold relief by the use of imagery, contrast, irony, hyperbole and other devices to depict the "immeasurable pain" that his environment is subjected (Nwagbara, 2011). He laments thus: 
I live in the deathbed prepared by a cabal of brokers breaking the peace of centuries $\&$ tainting not only a thousand rivers, my lifeblood from the beginning, but scorching their sacred soil was debauched by prospectors, money-mongers?

He refers to those who through their own selfishness annihilate the nature as "a cabal of brokers" and "prospectors, money-mongers".

\section{Conclusion}

The paper has established that Niyi Osundare and Tanure Ojaide have not only engaged in writing 'nature' for the sake of writing, but they have through their poetry addressed many issues bothering on the natural environment. This ranges from the emphasis on the beauty of nature, therapeutic power of nature, protective power of nature, the providential power of nature, and a great advocate to desist from destroying the nature particular the capitalistic tendencies of the imperialists in the commodification of natural endowments. Therefore, these poets though celebrate nature's beauty and potentials, they also use their poems to chastise humanity and urge moral and social change in favour of the natural environment. Also, it is noticeable that the poets' particular environments influenced the form and style of their poetry. And base on this, it is clear that there are more environmental challenges in the contemporary world of Tanure Ojaide which his poetry reflects.

\section{References}

Anyokwu, Christopher (2015). The Essentials of Niyi Osundare's Poetry. Transnational Literature, 8(1), 1-11. http:// fhrc.flinders.edu.au/transnational/home.html.

Arnold, Stephen. (2001). I Am One of Africa's Accidents: Interview by Stephen Arnold. Nigerian Writing and the Struggle for Democracy, edited by Holger Ehling and Claus-Peter Holste-von Mutius, Armsterdam - New York, 161-177.

Ayinuola, I. Fortress. (2013). The Natural Environment in the Selected Poems of John Keats and Niyi Osundare: An Eco-Critical Perspective. A Thesis Submitted to the Department of Languages, College of Development Studies (CDS) of Covenant University Ota, Nigeria.

Jeff, G. Doki. (2009). The Eye of the Earth: Niyi Osundare as a Poet of Nature (Pp. 66-77). African Research Review, 3(2), 66-77.

Nwagbara, Uzoechi. (2010). Poetics of Resistance: Ecocritical Reading of Ojaide's Delta Blues \& Home Songs and Home Song and Daydream of Ants and Other Poems. African Study Monographs, 31(1), 17-30.

Nwagbara, Uzoechi. (2011). In the Shadow of the Imperialists: A Philosophico-Materialist Reading of Tanure Ojaide's Delta Blues \& Home Songs and Daydream of Ants and Other Poems. SKASE Journal of Literary Studies, 3(1), 7696. http://www.skase.sk/Volumes/JLS03/pdf_doc/05.pdf.

Nwagbara, Uzoechi. (2008). Political Power and Intellectual Activism in Tanure Ojaide's The Activist. African Nebula, (5) 4, 225-253.

Nwagbara, Uzoechi. (2013). Nature in the Balance: The Commodification of the Environment in Niyi Osundare's The Eye of the Earth. Nordic Journal of African Studies, 22(3), 196-212.

Ohaeto, Ezenwa. (2003). Niyi Osundare and the Poetic Statement of a Generation. The People's Poet: Emerging Perspectives in Niyi Osundare, edited by Abdul-Rasheed Na'Allah, African World Press Inc, 27-38.

Ojaide, Tanure. (1995). Poetic Imagination in Black Africa. Carolina Academic Press.

Ojaide, Tanure. (1997). Delta Blues \& Home Songs. Kraftgriots, 1997.

Ojaruega, E. Eseoghene. (2015). The Place of Urhobo Folklore in Tanure Ojaide's Poetry. Tydskrif vir Letterkunde, 52(2), 138-158.

Oyeniyi, Okunoye (2011). Writing Resistance: Dissidence and Visions of Healing on Nigerian Poetry of the Military Era. Tydskrif vir Letterkunde, 41(1), 64-85. 
Osundare, Niyi. (1983). Songs of the Marketplace. New Horn Press.

Osundare, Niyi. (1986). The Eye of the Earth. Heinemann, 1986.

Tsaaior, T. James. (2011). Exile, exilic consciousness and the poetic imagination in Tanure Ojaide's Poetry. Tydskrif vir Letterkunde, 41(1), 98-109.

Cite this article as: Oluwafemi Sunday A labi (2021). Between the praiseand defense of nature: An ecocritical discourse of N iyi Osundareand TanureOjaide's eco-poetry. International Journal of L anguages and Culture. 1(2), 1-7. doi:10.51483/ IJLC.1.2.2021.1-7. 